\title{
SRIKANDI SUNGAI INDONESIA: THE ROLE OF WOMEN IN WATER CONSERVATION
}

\author{
FatkhuRohmatin, S.K. Habsari \\ Cultural Studies Department, Universitas Sebelas Maret Surakarta, Central Java, Indonesia \\ English Department, Universitas Sebelas Maret Surakarta, Central Java, Indonesia \\ fatkhurohmatin2@student.uns.ac.id, skhabsari@staff.uns.ac.id
}

\begin{abstract}
Srikandi Sungai Indonesia (Srikandi of Indonesian River) is an environment care organization which is managed by some women from various professions who care to the environmental issues of river. These women consider the importance to create networking with those who cares to environment, especially river because they consider that river in Indonesia are still important to provide domestic needs such as clean water for drinking and cooking and for washing and bathing as well. For some regions in Indonesia, river also functions as a space for public activities because many transportations and markets run on rivers. Therefore, this study aims to explore the preception of the women who join Srikandi Sungai Indonesia, especially Srikandi Sungai Indonesia in the Klaten Regency of why they consider taking responsibility to care rivers.
\end{abstract}

\section{Keywords: Women's role, Environment Care, River, Water Conservation, Pollution}

\section{Introduction}

Indonesia is a country which has many rivers, both large rivers and small rivers. However, the pollutant level of most rivers in Indonesia is quite alarming. Data from BPS (Central Bureau of Statistics) in 2016 regarding the status of rivers water quality with a sampling point of 72 large rivers in various islands in Indonesia show that the majority of rivers water in Indonesia has been polluted with quite varied levels, ranging from light scale pollution to heavy scale. Even, the Citarum River, one of the rivers on the island of Java is categorized as one of the dirtiest rivers in the world (Belinawati, et al, 2018).

This alarming condition should be homework for all people, considering that a river is still one of the important aspects of living in Indonesia. For some areas, a river is still an important natural resource to provide the community for clean water to drink and cook. Unfortunately, many people do not have a concern to keep the cleanliness of their environment, such as to keep the river from being polluted from either household or factory waste. In some areas, people still use a river for activities, such as bathing and cleaning, which in some way also create an environmental issue because of their use of unbiodegradable detergent. Some people in urban areas still throw away their domestic waste to 
rivers. Their behaviors show their low understanding to care their environment, especially rivers from pollutants. Such situations attract some women to engage with environment, especially rivers. They create a networking and form an organization, Srikandi Sungai Indonesia (SSI). Questions arisen are why they do concern to their environments, especially rivers and what motivations drive them to develop activities of environmental care.

Many studies have shown the significant roles of women on natural resource management. Women are also considered as the major contributors to environment protection (Aye, 2018). Women's direct interaction with the environment has enhanced their understanding and knowledge on how to preserve and rehabilitate environment because of their concern to have healthy lives (Ibid). Similarly, "women play an essential role in the management of natural resources, including soil, water, forest, and energy" and "often have a profound traditional and contemporary knowledge of the natural world around them" (World Bank, 1991). All opinions derived from these studies confirm the theory that women's link to nature is their source of power and strength, an argument developed by ecofeminist (Sydee and Beder, 2001, p. 284).

Moser (1989) has distinguished three women roles of "reproductive, productive and community managing world" (p. 1801). In correlation to environmental and ecological improvement and protection, women can be "the managers or the maintainers of the natural environment"; or/and "the rehabilitators of the natural environment in the sense of sustainable development"; or/and the innovators in the use of appropriate technology in the creation of new environment" (Wuyep, et.al. 2014, p. 32). Again, it is also to validity that women should be the ecological and social leaders when it is about environmental management. Related to these statements, Maneya (1996) has argued that "the importance of women in environmental management to achieve sustainable development can only be realized if women are given a chance to prove their worth in the development process" (p.9). This argument is derived from the fact found in many areas in the world that women's reproductive labor is necessarily excluded from the formal economy. However, women are also found out developing alternative reality to cope with the environmental issues which they consider damaging their healthy life.

The close relationship between women and the environment, especially water resource is also conveyed at the Second World Water Forum of United Nations in The Hague (2000). This forum recognizes that women are the prime users of domestic water because 
water has a key role in food production. Thus, women and children are the most vulnerable in water-related disasters (Sandys, 2005, p. 3). "Since women are responsible for fetching water for household use they should be fully integrated into planning and implementation of water management project" (Maneya, 1996, p.3). Recognizing the rights of women and men in managing their own resources is very needed to ensure that remaining resources are conserved and substitute resources are identified. Similarly, at the international Conference on Freshwater in Bonn (2001) the policy statement has underlined the need of gendered approach concerning both men and women in water resources management, to suggest that "the role of women in water related areas needs to be strengthened and their participation broadened" (IELRC, 2001, p.2). The gender approach in terms of water management can be seen as an effort to equal distribution of roles between men and women in the following fields: “i) access to information; ii) physical work; iii) contributions in time and cash; iv) decision-making; and v) access to and control of resources and benefits" (Sandys, 2005, p. 4).

Derived from these previous researches on 'environment and gender', this research attempts to explore the women's initiatives and activities to preserve environment from various pollutants, especially rivers which are still very important for Indonesians' life. Considering the activities of some women who join the organization of Srikandi Sungai Indonesia, which right now has spread to various regions in Indonesia, this research considers to discuss the preception of the women who join Srikandi Sungai Indonesia, especially Srikandi Sungai Indonesia in the Klaten Regency of why they consider taking responsibility to the river care.

\section{Method}

Srikandi Sungai Indonesia is an environmental organization and movement that spread across many regencies in Indonesia. For achieving the goal of the research, Srikandi Sungai Indonesiain Klaten Regency is chosen because the activities of Srikandi Sungai Indonesia in Klaten have been recognized by the Indonesian government and have also been used as model for environmental activities for the other activists of Srikandi Sungai Indonesia in other regions (Marwoto, 2018). The primary data were collected through a semi-structured questionnaire to 27 women activists of the organization. 7 activists hold positions as SSI daily administrators. While 20 activists are members of SSI from 10 different districts: Kemalang, Wedi, Central Klaten, Bayat, Cawas, Polanharjo, South Klaten, Prambanan, Kalikotes, and Karangnongko. To understand whether all members share similar perspective 
on the idea of gender and environment, this research purposively chooses two respondents from each district which fulfill the criteria of actively participating in SSI programs and on SSI social media.

The questionnaire is developed from the paradigm of gender and environment studies that focus on understanding women's perspective and responsibility on environmental issues, whether their environmental responsibility are considered as the extension of the defined sex roles or they have a different imagination and definition of the issue of women and environment which earn their activities as a part of public roles.Thus, for the purpose of the study, the questionnaire is organized into two part. The first part consists of questions to identify the individual identity of the respondents, such as name, age, sex, profession, academic qualification, address, and position in the SSI. The second part consists of 18 questions covering topics to understand their motivation, perspective, and action on SSI as environmental organization and environment, especially water and river. These questions are grouped into 4 categories, namely:

\section{Motivation to join SSI}

- How do you know about SSI?

- What do you know about SSI?

- Why have you decided to join SSI?

- How long have you joined SSI?

- What is your impression after joining SSI?

- What are your hopes for SSI in the future?

- As a member of SSI, how important is it for everybody to protect the environment (especially rivers)? Why do you consider that environment is everybody's responsibility?

- As a woman, why do you think that a river is important for you? Do you consider also that river is important for your family?

- As a woman, how important is health, cleanliness and environmental preservation for you (also for your family)?

\section{Action to conserve river}

- What activities have you participated in while joining SSI?

- What is your suggestion of how to maintain the cleanliness of the river environment?

- As a member of SSI, what do you do when someone throws garbage into the river or damages the environment around the river?

- As an SSI member and also as a mother, how do you educate your children to have a care to the environment, especially the river environment?

- As a member of SSI, what do you do to make all levels of society care their environment, such as maintaining the cleanliness of the river? 
- What are your suggestions and expectations for the community (especially Klaten - Indonesia in general) in relation to the sustainability of the river environment?

Criteria of an ideal healthy river

- In your opinion, what are the criteria for a healthy river environment?

\section{Access to river sources}

- As women, do you think that you share similar perspective on the need to care environment, especially river with your husband or the other men whom you meet?

- By becoming a member of SSI, how is the response of the closest people to your perspective and participation on the enviromental movement? (do they provide support?)

- In your opinion, who do you think has the greatest obligation to maintain the river environment?

The following data are the identity of the respondents from the members of SSI Klaten (Table 1):

\begin{tabular}{|c|c|c|c|}
\hline Respondents & Number & Districts & Professions \\
\hline $\begin{array}{l}\text { Daily } \\
\text { Administrator }\end{array}$ & 7 & $\begin{array}{l}\text { Wedi, Klaten } \\
\text { Tengah, Panggang }\end{array}$ & $\begin{array}{ll}- & \text { Goverment employees } \\
\text { - } & \text { Goverment employees } \\
\text { - } & \text { Lecturer } \\
\text { - } & \text { Village apparatus } \\
\text { - } & \text { Lecturer } \\
\text { - } & \text { Lecturer } \\
\text { - } & \text { Goverment officials of Klaten } \\
& \text { Regency }\end{array}$ \\
\hline \multirow{8}{*}{$\begin{array}{l}\text { Members of } \\
\text { SSI } \\
\text { (activists) }\end{array}$} & \multirow[t]{8}{*}{20} & 2 Panggang & $\begin{array}{ll}\text { - } & \text { Enterpreneurs } \\
\text { - } & \text { Student } \\
\end{array}$ \\
\hline & & 2 Bayat & $\begin{array}{ll}\text { - } & \text { Teacher } \\
\text { - } & \text { Enterpreneurs } \\
\end{array}$ \\
\hline & & 2 Karangnongko & $\begin{array}{ll}\text { - } & \text { Teacher } \\
\text { - } & \text { Enterpreneurs } \\
\end{array}$ \\
\hline & & 2 Kalikotes & $\begin{array}{ll}\text { - } & \text { Goverment employees } \\
\text { - } & \text { Goverment employees } \\
\end{array}$ \\
\hline & & 2 Prambanan & $\begin{array}{ll}\text { - } & \text { Goverment employees } \\
\text { - } & \text { Goverment employees } \\
\end{array}$ \\
\hline & & 2 Klaten Selatan & $\begin{array}{ll}- & \text { Housewife } \\
- & \text { Muslim Clergy }\end{array}$ \\
\hline & & 2 Wedi & $\begin{array}{ll}\text { - } & \text { Enterpreneurs } \\
\text { - } & \text { Enterpreneurs }\end{array}$ \\
\hline & & 2 Cawas & - $\quad$ Housewife \\
\hline
\end{tabular}




\begin{tabular}{|c|c|c|c|}
\hline & & & - $\quad$ Housewife \\
\hline & & 2 Klaten Tengah & $\begin{array}{ll}\text { - } & \text { Goverment employees } \\
\text { - } & \text { Enterpreneurs }\end{array}$ \\
\hline & & 2 Polanharjo & $\begin{array}{ll}\text { - } & \text { Tourism Business } \\
\text { - } & \text { Tourism Business }\end{array}$ \\
\hline
\end{tabular}

Table 1. Data of theIdentity of the Respondentsof SSI Klaten

The second part of the questionnaire are employed through formal to informal interviews. The interviews are conducted while doing the field observation through joining some SSI Klaten activities, such hydroponic and waste management training. Thus, the study could gain the benefit of understanding their answers through correlating with their activities they are conducting and their behaviors in communicating with other members. To support the primary data, this study also use secondary data that have been collected through over viewing various documents from Klaten Bureau of Statistic (BPS Klaten) and their activity on social media.

\section{Gender-based Water River Use in Klaten Regency}

Klaten is one of regencies in Central Java that has many rivers. According to BPS Klaten data (2014) there are 80 rivers across the Klaten Regency. For residents of Klaten, a river has become part of everyday life. In addition to fulfilling domestic needs, river is also one of the economic resources for Klaten's residents. They take water from rivers for agricultural irrigation, especially for rice fields. The cleanliness of some rivers in Klaten initiates some people to create water-based tourism and recreation. Scrutinizing the life of people in Klaten, it shows that a river is very important in their life, not only as a water source for domestic uses or household purposes, but also for rice field irrigation and water tourism which is now popular and can increase the community's income. It is not surprising if people of Klaten, both men and women consider preserving rivers as one of natural resources and sustaining the quality of rivers' water to be maximally utilized for their life.

With regard to the use of water in Klaten, there is a slight difference in proportions from gender perspective, that make both genders feel responsible to keep water quality sustainability. The following is a table describing gender position in the use of rivers in Klaten for daily life:

\begin{tabular}{|l|c|c|c|c|}
\hline \multirow{2}{*}{ No } & Activities & \multicolumn{3}{c|}{ Major Responsibility } \\
\cline { 3 - 5 } & & Female & Male & Both \\
\hline 1 & Cooking (washing cooking ingredients, & $\mathrm{V}$ & & \\
\hline
\end{tabular}




\begin{tabular}{|l|l|c|c|c|}
\hline & washing kitchen utensils, etc.) & & & \\
\hline 2 & $\begin{array}{l}\text { Washing clothes and household } \\
\text { appliances }\end{array}$ & V & & \\
\hline 3 & Bathing & & & V \\
\hline 4 & Defecating & & V & \\
\hline 5 & Irrigating & & V & \\
\hline 6 & Bathing and feeding livestock & & V & \\
\hline 7 & Management of water destination & & V & \\
\hline 8 & Fishing and growing fish in a pond & & & V \\
\hline 9 & Water tourism & & & \\
\hline
\end{tabular}

Tabel 2. Gender-based Water River Use in Klaten Regency

Observing gender-based use of water in Klaten, in some way it confirms to the previous findings that the men in Klaten use water for commercial purposes (see Radda, 1991). With the argument that water is source for economic productivity, men tend to exploit water as natural resources to increase their income (see Wenz ,2001). Meanwhile, women use water for domestic and household purposes, which earn them as the main drawers of water (see Bradley and White, 1972; Thompson, 2001). However, the finding of the study does not really correspond with the previous researches especially on the argument of the tendency of men to exploit water for increasing their income. Although the finding in Klaten shows similarity on gender-based use of water, with the commercial or economic sectors dominated by men, the increase of water tourism in Klaten involve women's participatory activities to run the sector. Although their activities do not need a direct contact with water, women play the important roles as tour guides, receptionists, or restaurant workers which have an important economic role. With an awareness that water does not only support their domestic life, but also provides an income for the family, the Klaten women do have responsibility to preserve the quality of water, especially the river water. That is why, they actively involved in educational activities, campaigns, supervision, and trainings in environmental conservation of water provided by environmental care organizations.

\section{Srikandi Sungai Indonesia (SSI)'s Activities on Water Conservation}

Srikandi Sungai Indonesia (SSI) was established in Yogyakarta, precisely on the banks of the river Code, Jetisharjo village on April 21 2016, after the first Indonesian River Congress in Banjarnegara, Central Java (Sahana, 2017). The aim of this environmentally care 
organization is to create a riverbank area that is friendly to children and women. It is interesting to note that women who join this organization come from different professional backgrounds, education, and ages.

SSI for the Klaten region was officially established by the Minister of Women's Empowerment and Child Protection (PPPA) on November 8, 2018. However, the activities of SSI Klaten have been recognized before the inauguration. Currently, the members of SSI Klaten are spread in each of sub-regency. Besides SSI, Klaten Regency also has several other environmental organizations. One of them is Sekolah Sungai Klaten (Klaten River School) community. In the interview, the leader of SSI Klaten has said that if Sekolah Sungai Klaten community focuses more on cleaning the river area, meanwhile the SSI Klaten is on education, campaigning, training, and mentoring. The target benefit of SSI activities is not only for women, but also for children to be able to utilize maximumly a healthy river environment for many purposes.

To achieve the four main mission of SSI Klaten (education, campaigning, training, and mentoring), some activities have been carried out by this organization since 2017 to January 2019.

\begin{tabular}{|l|l|l|l|}
\hline No & \multicolumn{1}{|c|}{ Date } & \multicolumn{1}{|c|}{ Place } & \multicolumn{1}{|c|}{ Activities } \\
\hline 1 & $\begin{array}{l}\text { January } \\
12,2019\end{array}$ & $\begin{array}{l}\text { Sub-Regency } \\
\text { Cawas, Klaten, } \\
\text { Central Java }\end{array}$ & $\begin{array}{l}\text { Workshop and comparative study of Wedi } \\
\text { sub-regency waste Bank 'Berkah' with waste } \\
\text { management activists from Cawas sub- } \\
\text { regency. }\end{array}$ \\
\hline 2 & $\begin{array}{l}\text { December } \\
20,2018\end{array}$ & $\begin{array}{l}\text { Prambanan, Klaten, } \\
\text { Central Java }\end{array}$ & $\begin{array}{l}\text { Joining the symposium 'water politics from } \\
\text { Central Java for Indonesia'. The event was } \\
\text { also attended by the river communities } \\
\text { throughout Central Java, BPBD (Regional } \\
\text { Disaster Management Agency) of Central } \\
\text { Java, and several organizations that care } \\
\text { environments. }\end{array}$ \\
\hline 3 & $\begin{array}{l}\text { November } \\
25,2018\end{array}$ & $\begin{array}{l}\text { Klaten, Central Java } \\
\text { Klaten Regency received an award from the } \\
\text { BPBD (Regional Disaster Management } \\
\text { Agency) for its success in reducing the risk of } \\
\text { floods through the initiation and development }\end{array}$ \\
\hline
\end{tabular}




\begin{tabular}{|c|c|c|c|}
\hline & & & $\begin{array}{l}\text { of river communities such as the Klaten River } \\
\text { School, SSI Klaten, and other river } \\
\text { communities }\end{array}$ \\
\hline 4 & $\begin{array}{l}\text { October } \\
17,2018\end{array}$ & Klaten, Central Java & $\begin{array}{l}\text { Organizing discussions with volunteers, the } \\
\text { Klaten River School community, village } \\
\text { officials, farmers, and activists. The main } \\
\text { focus is to socialize the movement of guarding } \\
\text { the river by 'not throwing garbage into rivers } \\
\text { and preparing for greening riverbanks during } \\
\text { the rainy season'. }\end{array}$ \\
\hline 5 & $\begin{array}{l}\text { September } \\
15,2018\end{array}$ & $\begin{array}{l}\text { Ujung River, Klaten, } \\
\text { Central Java }\end{array}$ & $\begin{array}{l}\text { In order to commemorate 'World Clean Day' } \\
\text { SSI collaborates with students, the Klaten } \\
\text { River School, BPBD Klaten, TNI (Indonesian } \\
\text { National Army), and other communities to } \\
\text { carry out cleaning activities in Ujung river, } \\
\text { Klaten. }\end{array}$ \\
\hline 6 & $\begin{array}{l}\text { September } \\
12,2018\end{array}$ & $\begin{array}{l}\text { Dispertan } \\
\text { (Agricultural } \\
\text { Office), Klaten, } \\
\text { Central Java }\end{array}$ & $\begin{array}{l}\text { Organizing a hydroponic training at Klaten } \\
\text { agricultural office (DISPERTAN) with } \\
\text { participants from GAPOKTAN (the affiliation } \\
\text { of farmer groups). In this event, SSI } \\
\text { consistently brings the message 'reuse used } \\
\text { goods' }\end{array}$ \\
\hline 7 & $\begin{array}{l}\text { August } \\
23,2017\end{array}$ & $\begin{array}{l}\text { Banaran Village, } \\
\text { Klaten, Central Java }\end{array}$ & $\begin{array}{l}\text { In collaboration with Alfa Mart, SSI provided } \\
\text { education and training on waste management. }\end{array}$ \\
\hline 8 & $\begin{array}{l}\text { July 25, } \\
2017\end{array}$ & Klaten, Central Java & $\begin{array}{l}\text { SSI received a visit from the environment } \\
\text { team and disaster management of the Union of } \\
\text { Doctors Aisyiyah Klaten. }\end{array}$ \\
\hline 9 & $\begin{array}{l}\text { May 27, } \\
2017\end{array}$ & $\begin{array}{l}\text { Lunyu River, } \\
\text { Klaten, Central Java }\end{array}$ & $\begin{array}{l}\text { SSI contributed to the'Ramadhan Market' } \\
\text { event held in Lunyu river, Klaten. This event } \\
\text { was a medium to promote 'the Lunyu River } \\
\text { Park' ecotourism. }\end{array}$ \\
\hline 10 & $\begin{array}{l}\text { April 27, } \\
2017\end{array}$ & Klaten, Central Java & $\begin{array}{l}\text { Socialization of the reuse of waste materials } \\
\text { into handicraft products that are useful and }\end{array}$ \\
\hline
\end{tabular}




\begin{tabular}{|l|l|l|l|}
\hline 11 & $\begin{array}{l}\text { January } \\
24,2017\end{array}$ & Klaten, Central Java & $\begin{array}{l}\text { Worth selling. } \\
\text { Contributing to discussions on environmental } \\
\text { and disaster management with the government } \\
\text { of Central Java and other river communities. }\end{array}$ \\
\hline & Etc. & & \\
\hline
\end{tabular}

Tabel 3. SSI Klaten Activities since 2017 to January 2019

There are still a lot of activities which are not mentioned on the list. Since the organization has been founded, all are committed to carrying out its main mission in the fields of education, campaigning, training, and mentoring.

In talking to the leader of SSI, she has explained that although the main mission of the organization to preserve the quality of rivers' water, they also have side mission which they consider important because it is related to the life quality of the people. Campaigning for action 'do not throw trash on the river', SSI Klaten considers that they also prevent disease and violence against women and children. The campaign is to respond the program of the Ministry of Pemberdayaan Perempuan dan Perlindungan Anak (Women's Empowerment and Children Protection) which highlights the need of good quality water because the absence of adequate water and sanitation services can potentially cause women and children to be vulnerable to various forms of violence. In some areas, people still defecate or build their toilet on top of rivers which are also used for bathing or washing (see Sahana, 2017). Therefore, the minister ofWomen's Empowerment and Children Protection prohibits the construction of toilets along the river area to prevent sexual harassments against women and children (Assifa, 2018).

The SSI Klaten activists are aware that their campaign will not be successful without any support from levels of society. They are also aware that it is not easy to change society's perspective and behavior toward their environment. Thus, they need to develop certain strategy to encourage public to support and participate their movement. Their campaign is not only focused on to the health impact of their participation to keep the cleanliness of rivers, but they also think to develop a program which is some way creative and has a potency to produce an economic impact.

In a campaign to "do not throw trashes into rivers", SSI Klaten develop a program "choose and separate" thrashes before they throw away. They create a waste bank 
management and train the people to open their mind and change their habit not throwing all reusable garbage into bins. Rather, they are asked to reuse some products and recycle some garbage materials into some other usable products that have selling values.

The idea of waste bank management is not something new in developing countries. Even, the idea of the '3Rs' model of Reducing, Reusing, and Recycling Waste Bank management is considered as an effective and efficient strategy to overcome waste problems that pollute environment (Peprah, Amoah and Achana, 2015; Visvanathan and Norbu, 2015; Chiu, 2010). The SSI Klaten takes such idea to propose people not throwing away their inorganic waste. Rather, they ask people to collect the inorganic materials such as plastics waste and sell them to the waste bank. The people of waste bank then change the waste into some crafts which have economic values.

Besides building waste bank, the SSI Klaten has also conducted some educational training on reforestation of riverbanks and hydroponic farming techniques. The reforestation of riverbank training aims to provide awareness to the community of the dangers of erosion when rainy season arrives. Meanwhile, the training of hydroponic farming techniques which focuses on utilizing household waste media which can be decomposed by bacteria is purposed to change the perspective of the public on the beneficial impact of applying such farming technique on both the health and the economy of the family. They also encourage public to see the impact of their small contribution to wider public, that is to keep availability of the quantity and quality of the produce in the dry season as well as to solve the problem of waste that pollutes environments.

In carrying out these four main missions, SSI Klaten cooperates with various communities such as the Sekolah Sungai Klaten (Klaten River School), volunteers, students, government organization etc. Through building networking and cooperation with many institutions which involves the participation of men and women, the SSI Klaten attempts to share their perspective that women and men have equal access and responsibility to environmental resources and issues which could endanger it. Collaboration with many institutions that have the authority to make policies and to encourage people to participate are beneficial to the progress and the success of the movement. To reach a broader impact, the SSI activities such as joining the symposium of 'water politics from Central Java for Indonesia' on December 20, 2018 and with contributing tothe discussions on environmental and disaster management with the government of Central Java and other river communities 
on January 24, 2017 are conducted not only to create a networking among many institutions but also to state that they share similar concerns which are in the need of supporting each other.

Understanding the activities of the SSI Klaten under the paradigm of gender and environment studies, it shows that the women of SSI Klaten have applied a gender-sensitive approach and integrated gender equality in addressing environmental issues (see Khosla, et.al. 2004, p.13; Douma, et.al. 2002). Through building networking with many institutions that include men as the actors of the activities, the SSI Klaten gains supports from all levels of society. To emphasize, through such actions, they do no need to raise up their voice to ask men's partnership in developmental issues, rather men voluntarily join the actions for an awareness of sharing benefits complementarily. In line with their actions, the government institution of Klaten acknowledges their contribution to environmental care and management, in which according toSri Mulyani, the regent of Klaten, they have participated to Klaten's effort to accelerate gender equality and Klaten's participation on human rights and social justice campaign in the environmental field.

Some previous studies show that eventhough women have more concern on the environmental issues than men, they are less politically active to speak up (McStay and Dunlap, 1983; Mitchell, 1979; Andersen, 1975; Andersen and Cook, 1985; Bourque and Grossholtz, 1974; Welchand Secret, 1981). In line with this argument, Mc Stay and Dunlap (1983) has stated that women's lack of political activity is generally the cause of the low level of women's environmental activity.The low level of women political participation, according to Welch (1977), can be explained on three aspects:1) The political socialization explanation, that women are socialized to be politically passive; 2) The situational explanation, that women are socialized to have a role as mothers and home makers, only having small time and opportunities for outside activities, such as politics; 3) The structural explanation,that socioeconomics characteristics cause gender differences in political participation. Although the three aspects are also present in the situations of Javanese society, the traditional Javanese cultural prescription which highlights the value of the fluidity of gender roles as complementarity, the finding of this study leads to a different argument concerning gender and environment. Despite the facts which say that women's participation on the movement is still their extension of their domestic roles, especially when they mention that they participate because they think of the health and the welfare of the family, their actions to encourage all levels of the society to participate are not politically absent. Their strategy to create 
networking with the institution shows that their thought is political and their expected impact is wide in scope.

\section{Women's Perception in Interview Survey}

\section{Motivation to join SSI}

Regarding the nature landscape experiences, it shows that members of the SSI Klaten have different perceptionwhen stating'their concern for the environment and natural resources'. The perspectives, then, motivate them to join SSI and other environmental organizations in Klaten, such as KWT (Farmer Women Group), Klaten Hydroponics, and Waste Banks etc. From interviewing the members of the SSi Klaten, this research categorizes their motivation into 5 different reasons: individual, domestic, community, economical, and psychological reasons. The following are some examples of the responses of SSI Klaten members when being asked about their perspective on why they 'concern for the environment and natural resources':

1. Individual scope

“...Women are the biggest waste producers... the majority of women in Indonesia still use disposable menstrual pads. Most are disposed of in landfills and dumped in the river...From us garbage starts, from us the environmental care movement must begin immediately too..." (Student, 22 years old)

2. Domestic scope

“...Almost every activity of women (especially housewives like me) is closely related to the environment. Starting for providing food, disposing kitchen waste, women always have contact with nature. This closeness between women and nature makes women have important positions in environmental management activities..." (a housewife, 40 years old)

3. Community scope

"...For women keeping the environment and preserving it is a necessity. Women are the first school for their children. Therefore, to get a generation that cares about the environment, women are the front guard. Women must be able to provide education to their families, and also societies on how to protect and preserve the environment..." (a teacher, 46 years old)

4. Economical scope 
“...From hydroponic training, I can get a lot of benefits: friends, extra income, contributing to make the environment greener, providing healthy vegetables for the family, and certainly get new useful information. From learning about hydroponics, I can also reduce waste by recycling garbage for a planting medium...by loving the environment, as a mutual, environment can provide benefits to us..." (a Hydroponic business women, 42 years old)

5. Psychological scope

"...loving nature is part of the therapy for loving our self. Getting closer to nature can make our minds relax, so make nature as a friend..." (a Muslim cleric in RSJD/ asylum, 46 years old)

From the number of the SSI activists' perspectives, it can be seen that women with different ages and professions have different perception on environment. Their different perspective and motivation derived from their knowledge to their surroundings are big cultural capitals to contribute to policy making regarding environmental management, especially in water conservation. Roy and Grow (2004) have stated that because of the role of women in the domestic area, making women and others have different views on the management of domestic waste. They can also have different definitions of waste and priorities for handling. In line with this statement, Mukherjee states that as consumers and producers, caretakers of their families and educators, the important role in promoting sustainable development through their concern for quality and sustainability of life for present and future generations (2013, p 5). Not only concern in individual and domestic scopes, women, especially SSI Klaten members also actively maintain and socialize the importance of caring for the environment to the surrounding community, as is done by one member who works as a teacher.

The concern of SSI members for the environment is not only based on their role as individuals, domestic managers or members of the community, but also because of the benefits they obtain from the environment. It can be seen from the statement of the hydroponic business woman who get benefits from an economic perspective, and a Muslim cleric is benefited from psychological perspective. That environment has correlation with mental health has been suggested through findings fromseveral studies which argue that interactions with the environment and nature support the process of recovery of psychological problems (Kaplan, 1995), reduce anxiety and a sense of stress (Ulrich et al., 1991; Grahn and Stigsdotter, 2003; Hartig et al., 2003; Maas et al., 2009) improve mood (Hartig et al., 2003; 
Barton and Pretty, 2010) and increase focuses (Hartig et al., 2003; Ottosson and Grahn, 2005). While, other studies mention that green space in environment is related to human wellbeing (White et al., 2013) and it can decrease anxiety, depression, and stress (Beyer et al. 2014).

However, from individual interview with the SSI Klaten members as explained above, it seems there is a contradiction between the perspective of the head of the SSI Klaten and the members. Although the government recognizes the actions of the SSI Klaten as politically environmental movement, the motivations of the members to join is still the extension of their domestic roles. From the perspective of the women of the grassroots level, the study still shares similar findings from the previous researchesthat gender difference exists in environmental concerns and women have a tendency to have deep concern to environmental issues because of their caring and nurturing attitude socialized through gender prescription from childhood (Arcuryetal., 1987; Blocker and Eckberg, 1989; McStay and Dunlap, 1983).

\section{Action to conserve river}

When the SSI Klaten members take actions, their motivation can be categorized into three different actions: individual, collective, and close relationships that show their level of activity.

1. Individual action

"Do not throw garbage, especially menstrual pads and shampoo into the river, you should use menstrual pads that can be used repeatedly and made from environmentally friendly ingredients ..."

"Sorting and recycling waste into valuable items."

2. When you see someone throwing garbage into the river

"Reprimand in order to dispose of garbage where it should be."

"Teach them how to manage waste properly."

3. Makes children, families and societies care about the river environment

"Familiarize environmental care with children from an early age."

"Teaching children to sort waste and throw it in its place."

"Familiarizing the family to recycle waste into hydroponic media and goods of economic value."

"Socialize the danger of flooding due to throwing garbage into the river."

"Prohibiting the construction of toilets around the river area." 
"Don't use chemicals to catch fish in the river."

From the various statements which can be categorized into their level of actions, scholars agree that women are considered as the pioneer or the frontline in protecting and preserving these resources. Women's closure to nature compared to men makes them as the perfect managers of an eco-systems. "They have their own devised system and ways to sustain and manage the resources which are the basis of survival for their families and communities" (Mukherjee 2013, p. 4). As the main manager of domestic water needs, women are accustomed to implementing effective conservation measured through their way of utilizing their local knowledge to overcome drought and scarcity of water resources (Mimi, Sinokrt and Tibi, 2011). Women are accustomed to managing water by recycling, monitoring water quality, disinfecting water, and sterilizing water sources. They do this because women are very concerned about the quality of their families' health.

\section{Criteria of an ideal healthy river}

Regarding to the river environment, the SSI Klaten members also have different opinions when being asked about "the ideal river criteria". But in general, all agree that the ideal river environment is a river environment whose resources can be fully utilized without making damage to the ecosystem of the river environment. The following is one example of the statements of the members of the SSI Klaten regarding the ideal river criteria:

"The ideal river environment is a river environment that is free from waste so that river biota can live normally and avoid the risk of flooding. In addition, the banks of the river must be free from toilet construction so that river water can be utilized maximumly. The river environment must also be friendly for women and children, one of which is the availability of educational parks along the riverbank area. " (an entrepreneur, 46 years old).

\section{Access to river sources}

As stated previously, the questions developed for this research are derived from gender and environment studies, that women tend to be more concerned with environmental problems than men (Raudsepp, 2001). Although findings from various studies, such as arguments developed by the ecofeminist highlighting the close relationship between women and environment, disparities still exist in terms of access, control and benefit. In interviewing the members, when being asked about access to river sources, surprisingly they mention their 
need to have similar access to river resources with men and they acknowledge their equality and complementarity in terms of control and benefit.

"As members of SSI, we have equal access to men to utilize river resources."

"My family and husband strongly support my activities as a member of SSI."

"SSI women are often invited to make river management rules."

The answers to the question indicate that gender gap in accessing to river sources, between men and women, for the SSI Klaten activists, tend to be slight (see Andersen, 1975; Andersen and Cook, 1985; Bourque and Grossholtz, 1974; Lansing, 1974; McDonagh, 1982; Milbrath, 1965; Smith et al., 1980; Welch and Secret, 1981).

\section{Women's Roles on Water Conservation as an empowerment}

Batliwala has argued that empowerment is "the process of challenging existing power relations, and of gaining greater control over the sources of power". One of the goals of empowerment is to enable poor women to gain access to, both informational and material resources (1994: 130). While, others mention that empowerment is a process by which women are able to control themselves to improve their own self-reliance, use their human rights to make choices and utilize existing resources (Keller and Mbewe, 1991), define selfinterest, and consider themselves as not only able, but entitled to make choices (Rowlanda, 1995; Kabeer, 1999). Women's empowerment is measured through their autonomy, agency, capacity for action, self-confidence and self- determination (Narayam, 2005; Hansen, 2015, Malhotra et al., 2002).

The SSI Klaten women's awareness to care the environment and their involvement in the SSI organization show that they are empowered individuals. The head of the SSI Klaten, especially has all the quality of autonomy, agency, capacity for action, self-confidence and self-determination when she develops some programs for campaigning and creates networking to include men on the actions. The success of the SSI Klaten is caused by the empowerment of all members who have the autonomy to participate and act and their awareness that they have the right to get all benefits from good environment. From all the statements, it shows that they are aware that good environment is their resource to get healthy life and happiness of their family. Meanwhile, they consider that the SSI Klaten is their agency to achieve their purpose because through joining the SSI Klaten they create networking among women who share similar concern on environmental issues and work together to change the perspective and the behavior of public on the need to care and protect 
their water rivers and river banks. In their collective action on cleaning the water river and changing the river banks into educational parks which have green tourism attraction, the main goal of the SSI Klaten is achieved. To emphasize, what the SSI Klaten have conducted shows the three dimensions of empowerment process in their way of utilizing resources and agency to achieve their main goal with providing benefits for all (see Kabeer 1999).

When referring to the opinion of Rowlands (1998) who divided the empowerment process into three levels, (individual empowerment, empowerment of collective groups, and empowerment in close relationships), this SSI Klaten organization could be said to have reached these three levels. Individual empowerment can be seen from the different perceptions of SSI-Klaten members on the importance of protecting the environment. This different perception is caused by different backgrounds in age, profession, education and other aspects. This perception then encouraged SSI members to take part in efforts to preserve the environment, especially the river. Meanwhile, collective empowerment is the result of the collaboration of members who have different backgrounds and perceptions to work together to achieve their intended goals. Collective empowerment within the SSI-Klaten organization can be seen from programs and organizational activities. Within the SSI-Klaten organization, this collective empowerment also helps to build and upgrade individual empowerments. By following this organization, the members' self-confidence and selfdetermination can be said to be increasingly honed. By participating in various programs in the SSI-Klaten organization, such as Hydroponics, Waste Bank, etc., Klaten women also contribute to the welfare of the economy and the level of family health (husbands, children, parents) and the community, this level is said to be an empowerment in close relationships.

\section{Conclusion}

The Gender-based Water River Use in Klaten Regency shows that there is no significant difference between the role of women and men in accessing river resources from the economic sector, although in the domestic sector it is still dominated by women because of their role as domestic managers. As found elsewhere, this study also verifies the notion that "women and nature have a relationship that cannot be separated, therefore women must be involved and play an important role in maintaining and managing the environment". However, this study highlights their perception and the activities developed to realize the goals derived from their motivation. 
The conversations to some members of the organization provide a picture that their main motivation in developing a lot of activities is to change the behavior of the people, especially in this study, the residences of Klaten. These women who join the SSI Klaten are apprehensive to the quite alarming pollution of the rivers in Klaten. They find out that people still have a habit to throw away their garbage to rivers. Fostered by their concern to normalize the water of rivers and the ecosystem of the rivers, they develop some strategic actions to achieve the goal of changing people's habit of throwing away their waste to the rivers and people's perspective of looking at waste as valuable materials.

Thus, the study argues that in the case of the SSI Klaten's activities for environmental care and protection, the need to apply gender roles and gender mainstreaming in water environmental management are negated because the women who join the organization have had a big awareness in the equal distribution of roles between man and woman. From the activities they have conducted, they show that they have equal access to information, contribution to time and pay, and access and control to sources and benefits. Their knowledge to their surroundings is their cultural capital to develop strategic actions which in some way are not directly related to the environmental care organization however it proves to be effective to reach the main goal of their organization. This study also states that involving women in policy making in the field of environmental conservation, especially rivers, is one of the women empowerment measures.

\section{References}

Andersen, K. (1975). Working women and political participation, 1952-1972. American Journal of Political Science, 19 (3), 439-453.

Andersen, K., and Cook E.A. (1985). Women, work, and poitical attitudes. American Journal of Political Science, 29 (3), 606-625.

Arcury, T. A., et al. (1987). Sex differences in environmental concern and knowledge: The case of acid rain. Sex roles, 16 (9/10), 463-472.

Assifa, F. (2018). Menteri Yohana kukuhkan 1.500 Srikandi penjaga sungai Indonesia.

Kompas.com. Retreived November 25, 2018, from

https://regional.kompas.com/read/2018/11/08/21033321/menteri-yohana-kukuhkan1500-srikandi-penjaga-sungai-indonesia 
Aye, T. T. (2018). The role of rural women in environmental management in Myanmar: A case study of Ngaputaw township. Open Science Journal, 3(1).

Barton, J., and Pretty, J. (2010). What is the best dose of nature and green exercise for improving mental health? A Multi-Study Analysis. Environmental Sciences and Technology, 44, 3947-3955.

Batliwala, S. (1994). The meaning of women's empowerment: New concepts from action. In Population Policies Reconsidered: Health, Empowerment, and Rights, Sen G, Germani A, Chen LC (eds). Harvard Center for Population and Development Studies: Boston.

Belinawati, R. A. P., et al. (2018). Sustainability: Citarum River, goverment role on the face of SDGs (water and sanitation). CSSPO 2018, E3S Web of Conferences 52,00038, https://doi.org/10.1051/e3sconf/20185200038

Beyer K.M.M., et al. (2014). Exposure to neighborhood green space and mental health: Evidence from the survey of the health of Wisconsin. International Journal of Environmental Research and Public Health, 11, 3453-3472.

Blocker, T. J., and Eckberg, D. L. (1989). Environmental issues as women's issues: General concerns and local hazards. Social Science Quarterly, 70 (3), 586-593.

Bourque, S. C., \& Grossholtz, J. (1974). Politics as unnatural practice: Political science looks at female participation. Politics and Society, 4(2), 225-266.

BPS Klaten. (2014). Name, clasification and length of river in Klaten Regency 2014.

Retrieved January 17, 2019, from

https://klatenkab.bps.go.id/statictable/2015/09/11/47/nama-klasifikasi-...1

BPS. (2016). Status kualitas air sungai, 2007-2016. Retrieved December 11, 2018, from https://www.bps.go.id/statictable/2014/09/05/1372/status-kualitas-air-sungai-2007--2016.html

Bradley, D.J., White, A.U., and White, G.F. (1972). Drawers of water: Domestic water use in East Africa. Chicago: The University of Chicago Press.

Chiu, A. Sf. (2010). The 3Rs and poverty reduction in developing countries. Japan: Institute for Global Environmental Strategies (IGES). 
Douma, A., et al. (2002). Towards a workable approach to mainstream gender in natural resources management. Amsterdam: Both ENDS.

Fatoni, N., Imanuddin, R., and Darmawan, A. R. (2017). Pendayagunaan sampah menjadi produk kerajinan. DIMAS, 17 (1), 83-96.

Grahn, P., and Stigsdotter, U. A. (2003). Landscape planning and stress. Urban Forestry and Urban Greening, 2, 1-18.

Hansen, N. (2015). The development of psychological capacity for action: the empowering effect of a microfinance programme on women in Sri Lanka. J. Soc. Issues 71, $597-$ 613.

Hartig, T., et al. (2003). Tracking restoration in natural and urban field settings. Journal of Environmental Psychology, 23, 109-123.

IELRC. (2001). Bonn international conference on fresh water ministeri all declaration. Switzerland: International Environment House.

Kabeer, N. (1999). Resources, Agency, Achievements: Reflection on the measurement of women's empowerment. Dev. Change, 30, 435-464.

Kaplan, S. (1995). The restorative benefits of nature: Toward an integrated framework. Journal of Environmental Psychology, 15, 169-182.

Keller, B., and Mbewe, D. C. (1991). Policy and planning for the empowerment of Zambia's Women Farmers. Canadian Journal of Development Studies 12 (1).

Khosla, P., et.al. (2004). Gender and water (Tematic overview paper). The Netherlands: IRC International Water and Sanitation Centre.

Krisanti, B. (2011, Februari). Ancaman di balik kepraktisan. Media Indonesia-Green Concern, p. 9.

Lansing, M. (1974). The American women: Voter and activist. In Women in Politics, ed. Jane S. Jaquette, pp. 5-24, New York: Willey.

LGA. (2013). Wealth from waste: The LGA local waste review. London: Local Goverment Association.

Maas, J., et al. (2009). Morbidity is related to a green living environment. Journal of Epidemiology and Community Health, 63, 967-973. 
Malhotra, A., Schuler, S. R., and Boender, C. (2002). Measuring Women's Empowerment as a Variable in International Development. Washington, DC: World Bank.

Maneya, E. (1996). A review of gender and environmental sustainability: Strategies for sustainable development in Zimbabwe. Pula ( Botswana Journal of African Studies), $10(1)$.

Marwoto, B. D. (November, 2018). Menteri berharap Srikandi Sungai di Klaten jadi percontohan. $\quad$ Retrieved December 12, 2018, from https://jateng.antaranews.com/berita/204351/menteri-berharap-srikandi-sungai-diklaten-jadi-percontohan

McDonagh, E.L. (1982). To work on not to work: The differential impact of achieved and derived statuss upon the political praticipation of women, 1956-1976. American Journal of Political Science, 26 (2), 280-297.

McStay, J.R., and Dunlap, R.E. (1983). Male-female differences in concern for environmental quality. International Journal of Women's Studies, 6(4), 291-301.

Milbrath, L.W. (1965). Political participation. Chicago: Rand McNally.

Mitchell, R. C. (1979). Silent springs/Solid majorities. Public Opinion, 2, 16-20, 55.

Moser, C. (1989).Gender planning in the thirdworld: Meeting practical and strategic gender needs. World Development, 17 (11), 1799-1825.

Mukherjee, R. (2013). Eco-feminism: Role of women in environmental governance and management. Galgotias Journal of Legal Studies, 1 (2).

Narayan, D. (2005). Measuring Empowerment: Cross-Disciplinary Perspectives. Washington DC: World Bank.

Ottosson, J., and Grahn P. (2005). A comparison of leisure time spent in a garden with leisure time spent indoors: On measures of restoration in residents in geriatric care. Landscape Research, 30, 23-55.

Peprah, K., Amoah, A.t., andAchana, G. T. W. (2015). Assesing '3Rs' model in relation to municipal solid waste management in Wa, Ghana. World Environment, 5 (3), 112120.

Radda, A. (1991).Women and environment. New Jersey: Zed Book ltd. 
Rainie, L., and Wellman, B. (2012). Networked: The new social operating system. Boston: MIT Press.

Raudsepp, M. (2001). Some socio-demographic and socio-psychological predictors of environmentalism. TRAMES, 5 (4), 355-367.

Rowlands, J. (1995). Empowerment examined. Development in Practice, 5 (2), 101-107.

Rowlands, J. (1998). A word of times, but what does it mean? Empowerment in the discourse and practice of development. In Women and Empowerment: Ilustrations from the third world, Afshar, H (ed). New York: St Martin Pren.

Roy and Grow. (2004). Gender relations and access to water: What we want to know about social relation and women's time allocation. California: University of California.

Sahana, M. (2017). Sekolah Srikandi Sungai, Partisipasi Perempuan Lestarikan Lingkungan dan Sungai. VOA. Retrieved November 25, 2018, from https://www.voaindonesia.com/a/sekolah-srikandi-sungai-partisipasi-perempuanlestarikan-lingkungan-dan-sungai/3896606.html).

Sandys, E. (Februari, 2005). Women and water. New York: United Nations, Division for the Advancement of Women, Department of Economic and Social Affairs.

Smith, et al. (1980). Participation in social and political activities. San Francisco: JosseyBass.

Sydee, J., and Beder, S. 2001. Ecofeminism and globalisation: A critical appraisal. Democracy \& Nature, 7 (2), 281-302.

Thompson, J. (2001). Drawers of Water: 30 Years of Change in Domestic Water Use and Environmental Health in East Africa. Summary Report. London: International Institute for Environment and Development.

Ulrich R.S., et al. (1991). Stress recovery during exposure to natural and urban environments. Journal of Environmental Psychology, 11, 201-230.

Visvanathan, C., and Norbu, T. (2015). Reduce, reuse, and recycle: The 3Rs in South Asia. Retrieved January 24, 2019 from https://www.researchgate.net/publication/266016733 
Welch, S. (1977). Women as political animals? A test of some explanations for male-female political participation differences. American Journal of Political Science, 21 (4), 711730.

Welch, S., \& Secret, P. (1981). Sex, race and political participation. The Western Political Quarterly, 34 (1), 5-16.

Welch, S., and Secret, P. (1981). Sex, race, and politial participation. The Western Political Quarterly, 34 (1), 5-16.

Wenz, P.S. (2001). Environmental ethich today. New York: Oxford University Press.

White M.P., et al. (2013). Would you be happier living in a greener urban area? A fixedeffects analysis of panel data. Psychological Science, 24, 920-928.

Women's Environmental Network. (1989). Whitewash. Women's Environmental Network Newsletter, (3), Spring.

World Bank. (1991). Women and development in Malawi: constraints and actions. Washington DC: World Bank.

Wuyep, S.Z., et al. (2014). Women participation in environmental protection and management: Lessons from Plateau state, Nigeria. American Journal of Environmental Protection, 2 (2), 32-36. 